\title{
CZESŁAW MIŁOSZ I TOMAS VENCLOV A O PRZESZŁOŚCI: TRADYCJA JAKO ŹRÓDŁO WSPÓLNOTY I POROZUMIENIA MIĘDZY LUDŹMI I NARODAMI ${ }^{1}$
}

\author{
VAIVA NARUŠIENE்2 \\ (Kowno) \\ Słowa kluczowe: Czesław Miłosz, Tomas Venclova, stosunki litewsko-polskie, \\ tradycja Wielkiego Księstwa Litewskiego \\ Keywords: Czesław Miłosz, Tomas Venclova, Lithuanian and Polish relations, \\ the tradition of Grand Duchy of Lithuania
}

\begin{abstract}
Abstrakt: Vaiva Narušienė, CZESŁAW MIŁOSZ I TOMAS VENCLOVA O PRZESZŁOŚCI: TRADYCJA JAKO ŹRÓDŁO WSPÓLNOTY I POROZUMIENIA MIĘDZY LUDŹMI I NARODAMI. „PORÓWNANIA” 10, 2012, Vol. X, s. 123-139, ISSN 1733-165X. W powojennej historii stosunków polsko-litewskich poczesne miejsce zajęła publiczna debata pomiędzy Czesławem Miłoszem a Tomasem Venclovą, która zaczęła się w roku 1979 na łamach paryskiej „Kultury” ich wspólnym Dialogiem o Wilnie i toczyła się prawie przez ćwierć wieku. W tym czasie, gdy polscy i litewscy działacze emigracyjni od kilku dziesięcioleci nie mogli znaleźć porozumienia w najważniejszych kwestiach, licytując się na dawno przebrzmiałe argumenty, ci ludzie sztuki dali przykład konstruktywnego dialogu. Miłosz i Venclova, dotykając najbardziej drażliwych kwestii stosunków polsko-litewskich, zwracają się do wspólnej historii i tradycji obydwu narodów oraz starają się pokazać korzenie niezgody, sięgające niekiedy dalekiej przeszłości. Wierzą bowiem, że tylko szczera rewizja przeszłości pomoże zburzyć przestarzałe stereotypy historyczne i narodowe, które przeszkadzają dojściu do porozumienia. Manifestowana w dyskusji postawa Venclovy, głosząca prymat tolerancji narodowej i kulturowej, była w głównej mierze oparta na wyznawanym przez niego kosmopolityzmie rozumianym w klasycznym sensie tj. jako "obywatelstwo świata”. Natomiast dla Miłosza główny punkt wyjścia do wszelkich rozważań stanowiła tradycja Wielkiego Księstwa. Jego koncepcja tolerancyjnego społeczeństwa, stającego ponad podziałami narodowymi i kulturowymi, zbliża się do idei społeczeństwa obywatelskiego.
\end{abstract}

\footnotetext{
Abstract: Vaiva Narušienė, CZESŁAW MILOSZ AND TOMAS VENCLOVA'S DISCUSSION ON THE PAST: TRADITION AS THE FOUNDATION OF NATIONAL BELONGING AND

${ }^{1}$ Artykuł powstał w ramach projektu „Post-doc“ finansowanego przez Radę Naukową Litwy.

2 E-mail Address: vaiva.narusiene@gmail.com
} 
SOLIDARITY. "PORÓWNANIA" 10, 2012, Vol. X, p. 123-139. ISSN 1733-165X. A public discussion between the poets Czesław Miłosz and Tomas Venclova, initiated by the article "Dialogue about Vilnius" in the Paris-based cultural journal in 1979 and continued for about a quarter of a century, plays a special role in the history of post-war Polish and Lithuanian relations. At those times when Polish and Lithuanian emigrants had unsuccessfully been trying to solve the most relevant issues for decades, these poets gave an example of a constructive dialogue. When addressing the most important and arguable issues associated with the Polish and Lithuanian relations, Miłosz and Venclova looked at the common history and tradition of both nations in order to identify the reasons of their disagreement that often stems from distant past. They believed that only an honest revision of history would enable breaking deeply ingrained historical and national stereotypes which prevent from reaching an agreement. In the discussion, Venclova stresses national and cultural tolerance, which he mostly bases on the idea of cosmopolitanism, referring to its usual meaning of "global citizenship". Meanwhile, the starting point of Miłosz's thoughts is the traditions of Grand Duchy of Lithuania. He advocates the conception of a tolerant multi-national and multi-cultural society which is similar to the idea of a civil society.

W powojennej historii stosunków polsko-litewskich poczesne miejsce zajęła publiczna debata pomiędzy Czesławem Miłoszem a Tomasem Venclovą. Powodem do rozpoczęcia trwającej blisko ćwierć wieku wymiany zdań stało się opublikowanie na łamach paryskiej „Kultury” w roku 1979 ich wspólnego Dialogu o Wilnie. W tym czasie, gdy polscy i litewscy działacze emigracyjni od kilku dziesięcioleci nie mogli znaleźć porozumienia w najważniejszych kwestiach, licytując się na dawno przebrzmiałe argumenty, ci ludzie sztuki dali przykład konstruktywnego dialogu. Rozmowy, stanowiącej jedyną skuteczną drogę do osiągnięcia zgodnego stanowiska we wspólnych sprawach.

Nietypowa historia przyjaźni Miłosza i Venclovy rozpoczęła się jeszcze przed rokiem 1977 tj. datą emigracji litewskiego poety do USA. Jej wynikiem była nie tylko wieloletnia współpraca twórcza 3 , lecz także dysputa, której dotyczy niniejszy artykuł. Ich spotkania nie można nazwać przypadkowym. Miłosza (ur. 1911 r., zm. 2004 r.), wówczas już wybitnego poetę i publicystę, związanego z paryską „Kulturą", i Venclovę (ur. 1937 r.), utalentowanego litewskiego poetę i tłumacza, autora dwóch zbiorów poezji, znanego z działalności dysydenckiej na Litwie i z Listu

3 Przyjaźń poetów zaczęła się właśnie od ich twórczości. Miłosz po raz pierwszy usłyszał o Tomasie Venclovie w 1972 r. od rosyjskiego poety emigranta Josifa Brodskiego, który zaprzyjaźnił się z nim podczas swego pobytu w Wilnie. Wyjeżdżając do USA, Brodski zabrał ze sobą pierwszy zbiór poezji Venclovy Kalbos ženklas (Znak mowy) (1972), z którym, będąc już w Ameryce zapoznał Miłosza. Ten przełożył i wydrukował w 1973 r. w paryskiej „Kulturze” jeden z wierszy Venclovy: Rozmowa w zimie, („Kultura” 1973, nr 5, s. 34-36). Dzięki pomocy Miłosza Venclova uzyskał pracę na uniwersytecie w Berkley, gdzie znalazł się w 1977 r. W tym czasie poezja Miłosza była już Venclovie doskonale znana. Przebywając w Stanach, zajął się między innymi tłumaczeniem jej na język litewski. 
otwartego do Centralnego Komitetu Komunistycznej Partii Litwy, złączył nie tylko sentyment do wspólnego ich młodości miasta - Wilna. Odczuwali wzajemną bliskość, jeśli chodzi o poglądy twórcze, a przede wszystkim aktywnie angażowali się w sprawy społeczne i polityczne. Przyjmowanie tego rodzaju postaw dyktował poetom odczuwany przez nich moralny obowiązek działalności na rzecz zbliżenia własnych narodów. Podejmując trudne tematy, wywołujące najwięcej sporów i kontrowersji, artyści starali się przełamywać panujące stereotypy, wytyczając $\mathrm{w}$ ten sposób narodom polskiemu i litewskiemu drogę do koniecznego porozumienia. Miłosz w Dialogu o Wilnie określił swoje stanowisko w następujący sposób:

I ty, i ja chcemy, żeby stosunki polsko-litewskie ułożyły się inaczej niż w przeszłości. Dwa narody mają za sobą straszne doświadczenia, zostały podbite, upokorzone, zdeptane. Nowe pokolenia inaczej będą ze sobą rozmawiać niż to działo się $\mathrm{w}$ latach przedwojennych. Musimy jednak liczyć się z siłą inercji i z tym, że w próżni ideologicznej, jaka powstała, nacjonalizm czy w Polsce czy w Litwie nieraz będzie wkraczał na utarte tory ${ }^{4}$.

Dialog o Wilnie, nazwany po latach „pierwszą poważną publiczną rozmową Polaka i Litwina po II wojnie światowej" 5 , nie był jedyną wspólną wypowiedzią poetów na temat stosunków polsko-litewskich. Żywo reagując na ówcześnie zmieniającą się sytuację polityczną w Europie, chcąc zapobiec możliwości ponownego konfliktu polsko-litewskiego, Venclova w 1989 r. na łamach paryskiej „Kultury" opublikował List otwarty do Litwinów i Polaków Litwy6. W odpowiedzi na wystąpienie Venclovy, Miłosz, w tym samym miejscu, przedstawił swoje stanowisko $\mathrm{w}$ artykule opatrzonym tytułem $\mathrm{O}$ konflikcie polsko-litewskim ${ }^{7}$. Ciągiem dalszym rozpoczętej pod koniec lat 70 XX w., a podjętej ponownie w 1989 r., dyskusji stały się ich wspólne, późniejsze wypowiedzi: Rozmowa o Litwie $(1990)^{8}$ oraz Żeligowski $i$ upiory przeszłości (1993) ${ }^{9}$. Problemy polsko-litewskie będą podejmowali także i w późniejszych latach. Temu zagadnieniu poświęcą uwagę między innymi podczas spotkania z Günterem Grassem oraz Wisławą Szymborską odbytym drugiego października 2000 roku w Wilnie ${ }^{10}$. Należy zauważyć, że oprócz wyżej wzmiankowanych wspólnych wypowiedzi, kwestie polsko-litewskie poeci podnosili wielokrotnie na własną rękę w licznych artykułach, wystąpieniach publicznych, wy-

4 Dialog o Wilnie. „Kultura” 1979, nr 1, s. 15.

${ }^{5}$ Żeligowski i upiory przeszłości. Z Czesławem Miłoszem i Tomasem Venclova rozmawia Elżbieta Sawicka. „Rzeczypospolita” 1993, nr 149, s. 22.

6 T. Venclova, List otwarty do Litwinów i Polaków na Litwie. „Kultura”, 1989, nr 3, s. 111-114; przedr. „Tygodnik Polski” 1989, nr 21, s. 16; „Lithuania” 1990, nr 1, s. 154-156.

${ }^{7}$ Cz. Miłosz, O konflikcie polsko-litewskim. „Kultura” 1989, nr 5, s. 3-9.

8 Cz. Miłosz, T. Venclova, Rozmowa o Litwie. „Odra” 1991, nr 1, s. 23-33.

9 Żeligowski i upiory przeszłości, op. cit., s. 22.

10 Pokalbiai apie atminties ateiti. Baltos lankos, Vilnius 2001. 
wiadach i książkach. Fakty te potwierdzają szczególną wagę, jaką przywiązywali do sprawy uregulowania stosunków między Polakami i Litwinami. Spośród wielu aspektów zasygnalizowanego powyżej zagadnienia w niniejszym artykule zostanie przeanalizowana podjęta przez Miłosza i Venclovę, jako reprezentantów kultury polskiej i litewskiej, rozmowa mająca w zamyśle artystów stanowić dyplomatyczną próbę uzgodnienia wspólnego stanowiska w imieniu zwaśnionych stron.

Wypowiedzi Venclovy i Miłosza (głównie w związku z autorytetem polskiego poety) nie przeszły bez echa. Spotkały się z zainteresowaniem zarówno ze strony polskiego i litewskiego społeczeństwa, jak i świata nauki po obydwu stronach. W tym miejscu należy wyróżnić artykuły Aleksandra Fiuta ${ }^{11}$ i Elżbiety Sawickiej ${ }^{12}$, a także monografię Viktoriji Daujotytė i Mindaugasa Kvietkauskasa pt. Lietuviškieji Česlovo Milošo kontekstai (Litewskie konteksty Czestawa Mitosza) ${ }^{13}$. W wymienionych analizach najwięcej miejsca poświęcono komentowaniu Dialogu o Wilnie. Dotychczas jednak brakowało prezentacji całości dyskusji i głoszonych w niej postulatów, co pozwoliłoby lepiej zrozumieć linię ideową, zarówno Miłosza jak i Venclovy. Takie przedstawienie dałoby ponadto podstawy do dokonania szerszych uogólnień, a także określenia miejsca niniejszej dysputy w rozwoju stosunków polskolitewskich. Ambicją autorki niniejszego artykułu, pomimo szczupłości dostępnej formy, jest zapełnienie, choć w części, powstałej luki poprzez chronologiczną prezentację i omówienie wypowiedzi poetów. Tak przyjęty układ pozwoli na prześledzenie ewolucji poglądów oraz zmian w podejmowanych przez poetów kwestiach w stosunku do zagadnień polsko-litewskich.

Jak wspomniano, początek do rozwinięcia wieloletniej dyskusji dał Dialog o Wilnie, w języku litewskim znany pod nazwą Wilno jako forma duchowego życia. $\mathrm{Na}$ jego treść złożyły się zamówione w 1978 r. przez Wiktora Woroszylskiego, redaktora czasopisma "Zapis”, listy literackie Miłosza i Venclovy. Miłosz oddał je Jerzemu Giedroyciowi, z prośbą o przekazanie ich do Polski na ręce Woroszylskiego. Tak jednak się nie stało. Giedroyć otrzymane teksty opublikował w swojej „Kulturze”14. Według Aleksandra Fiuta, Dialog o Wilnie odpowiadać miał zamierzonej przez Giedroycia kampanii politycznej, „której cel stanowiła poprawa stosunków polsko-litewskich (podobnie jak polsko-białoruskich czy polsko-ukraińskich). Więcej nawet: ułożenia tych stosunków na zupełnie innych zasadach, których fundamentem miało być (...) poszanowanie istniejących granic"15. Po

${ }^{11}$ A. Fiut, Spotkania poetów: Miłosz i Venclova. „Kwartalnik Artystyczny” 2004, nr 1, s. 9-29.

12 E. Sawicka, Dwa mury. Mitosz i Venclova: dialog o Polakach i Litwinach. „Polityka” 1989, nr 25, s. 8.

13 V. Daujotytė, M. Kvietkauskas, Lietuviškieji Česlovo Milošo kontekstai. LLTI, Vilnius 2011, s. 298-316.

${ }^{14}$ D. Mitaitè, Tomas Venclova. Biografijos ir kūrybos ženklai. LLTI, Vilnius 2002, s. 157.

15 A. Fiut, Spotkania poetów: Miłosz i Venclova, "Kwartalnik Artystyczny” 2004, nr 1, s. 10. Jeszcze w 1974 roku w artykule wstępnym nr 9 „Kultury” Juliusz Mieroszewski pisał, że Polacy powinni „zrezygnować raz i na zawsze z Wilna, Lwowa i jakiejkolwiek polityki czy planów, któryby zmierzały 
upływie dwudziestu pięciu lat, wspominając to wydarzenie, Miłosz uznał działanie redaktora „Kultury” za słuszne i w pełni usprawiedliwione. Między innymi właśnie dzięki temu, jak twierdził poeta, udało się Giedroyciowi dokonać wielkiego przełomu ideowego $\mathrm{w}$ myśleniu nacjonalistycznie nastawionej emigracji polskiej. Zabieg ten miał odnieść powodzenie dzięki propagowaniu przez redaktora „Kultury” polityki opartej na tradycji dawnej Rzeczypospolitej, której zwolennikiem był również Miłosz ${ }^{16}$. W Dialogu o Wilnie poeta-Polak i poeta-Litwin świadomie zwracają się ku przeszłości i tradycji, szukając „innych zasad”, stanowiących zaprzeczenie linii polskiego i litewskiego nacjonalizmu. Tylko przyjęcie takiej opcji politycznej dawało, według słów Miłosza, „nadzieję przyjaźni pomiędzy Polakami i Litwinami" 17 .

W swoim liście Miłosz omawia sprawy, które w końcu XIX i w pierwszej połowie XX stulecia, podczas konfliktu polsko-litewskiego, wywoływały najwięcej emocji. Były to: kwestie narodowościowe, spadku kulturowego oraz wartościowania historii ${ }^{18}$. Porusza także sprawę polonizowania się Litwinów, zwłaszcza szlachty, o której wiele dyskutowano w dziesięcioleciu poprzedzającym wybuch pierwszej wojny światowej ${ }^{19}$. Miłosz przedstawił swoje propozycje rozwiązania problemów, które w swoim czasie nie doczekały się rozwiązania, a po latach uległy zapomnieniu. Poeta dokonywał swoistej retrospekcji. Wierzył, że poruszane zagadnienia, przywrócone świadomości mu współczesnych, pomogą zmienić przedstawienie przeszłości, a przez to stworzyć podstawę do porozumienia. O zabiegu tego typu pisał w tym samym duchu Santos Juliá w artykule dotyczącym roli pamięci i przeszłości w budowaniu nowej tożsamości:

do ustanowienia w sprzyjającej koniunkturze naszej przewagi na Wschodzie kosztem cytowanych powyżej narodów. (...) Powinniśmy wrócić do Mickiewicza”. J. Mieroszewski, Rosyjski "kompleks polski” i obszar ULB. „Kultura” 1974, nr 9, s. 12, 14.

16 „„...co mnie łączyło z Giedroycem - Wschód i to znaczy pochodzenie i znajomość dawnych wschodnich ziem Rzeczypospolitej - zainteresowanie problematyką ukraińską, litewską, białoruską itd. Giedroyc dokonał wielkiego przewrotu - wbrew emigracji, która nie chciała słyszeć o oddaniu Wilna czy Lwowa, zrobił ten wielki skok, wielki przełom". Litwa, labirynt, nadzieja - z Czesławem Miłoszem rozmawia Krzysztof Myszkowski,. „Kwartalnik Artystyczny” 2004, nr 3, s. 39.

17 Dialog o Wilnie, op. cit., s. 15.

18 Według Piotra Łossowskiego, „...duże rozbieżności wywoływały dyskusje nad bardzo specyficznym (...) problemem, a mianowicie, kto w rzeczywistości był Litwinem i jak należy rozumieć pojęcie tej narodowości. Zagadnienie na pozór formalne kryło za sobą głębszy sens. Chodziło o prawo do dziedzictwa całej spuścizny historycznej Wlk. Księstwa Litewskiego, a także dorobku kulturalnego Litwy w pierwszej połowie XIX w. (...) Najwięcej wszakże miejsca zajmowała i najwięcej roznamiętnienia wzbudzała przez cały czas sprawa oceny wspólnej przeszłości, a zwłaszcza unii polskolitewskiej o jej roli. (...) Litwini w sposób stanowczy unię potępiali, zaś Polacy, w swej większości, coraz bardziej ją idealizowali". P. Łossowski, Po tej i tamtej stronie Niemna. Stosunki polsko-litewskie 1883-1939. Czytelnik, Warszawa 1985, s. 78-79.

19 P. Łossowski, Litewski ruch narodowy w polskiej myśli politycznej (1883-1914), w: H. Zieliński (red.), Polska myśl polityczna XIX i XX wieku. T. 1: Polska i jej sąsiedzi. Ossolineum, Wrocław 1975, s. 153. 
Chodzi o przeniesienie przeszłości do teraźniejszości po to, aby wartości, którymi ongiś kierowali się odrzuceni, zwyciężeni i zdeptani przez historię, przewartościowane przez pamięć socjalną, mogłyby posłużyć za narzędzie do budowania nowych tożsamości kolektywnych, narodowych albo nie ${ }^{20}$.

Mówiąc o Wilnie, Miłosz nazywa go „punktem odniesienia jako możliwość, możliwość normalności" 21 . W mieście tym rozpoznaje szansę powrotu do dawnego harmonijnego stanu rzeczy, który w zawierusze historii został zachwiany i zburzony. Wspominając Wilno swojej młodości, poeta przede wszystkim szuka ciągłości, jemu bliskiej tradycji Wielkiego Księstwa Litewskiego. Znajduje ją na Uniwersytecie Wileńskim, w lożach masońskich, w stowarzyszeniu Filomatów, w Klubie Włóczęgów, w ideologii krajowców wileńskich i „marzeniach federacyjnych" Józefa Piłsudskiego. Tradycję tę wiąże bezpośrednio z ideą jagiellońską, z którą kojarzy cechy idealnego państwa tj.: równouprawnienie narodowościowe i językowe, tolerancję wyznaniowa, możliwość pogodzenia patriotyzmu państwowego Rzeczypospolitej z patriotyzmami lokalnymi ${ }^{22}$. Wszystkie te elementy w znacznym stopniu, jak uznawał Miłosz, były charakterystyczne dla społeczeństwa przedwojennego Wilna. Miasto, o którym pisze, przedstawia jako tygiel, w którym od wieków żyją wspólnie, mieszając się, narody, kultury i religie. Przeplatające się wzajemnie różnorodności miały tym samym, w ujęciu Miłosza, stanowić nierozdzielną, naturalną jedność. Poeta z jednej strony przeciwstawia się antysemicko nastawionym nacjonalistom pochodzenia polskiego, jak i litewskiego, z drugiej podkreśla ważne miejsce wspólnoty żydowskiej w Wilnie, która stworzyła tu niezwykle mocny ośrodek kulturowy. Zdaniem poety, Wilno stanowi nierozłączną część kultury polskiej. W związku z tym każda próba podziału spadku kulturowego jest skazana na niepowodzenie, bowiem tacy ludzie jak Mickiewicz, Słowacki czy Piłsudski należą równocześnie do kultury polskiej, jak i litewskiej. Idea jagiellońska również objaśnia, dlaczego tak dużo uwagi poświęca Miłosz jej duchowym spadkobiercom - wileńskim krajowcom, próbującym stanowić opór wobec polskiego i litewskiego nacjonalizmu. Jak zauważa poeta, właśnie ten nurt najpełniej nakreślił w swojej doktrynie federalistyczną wizję Litwy jako państwa opartego na równouprawnieniu zamieszkujących $\mathrm{w}$ nim narodów litewskiego, polskiego i białoruskiego, połączonych pod wspólnym hasłem krajowości. O kierunku tym Juliusz Bardach pisał:

20 Santos Juliá, ¿Quélespasóa nuestros abuelos en la guerra? <http:/ / www.elpais.com/articulo/portada/les/ paso/abuelos/guerra/elpepuculbab/20110122elpbabpor_12/Tes> (tłumaczenie autorki).

${ }^{21}$ Dialog o Wilnie, op. cit., s. 3.

22 „Mit jagielloński (...) był także wyrazem tęsknoty za jakimś lepszym światem, światem, w którym nie będzie gwałtu i przemocy, w którym wszystkie narody cieszyć się będą wolnością i żyć zgodnie $\mathrm{z}$ zasadą "wolni $\mathrm{z}$ wolnymi, równi $\mathrm{z}$ równymi«. Innymi słowy, była to utopia przeniesiona w przeszłość”. J. Maternicki, Początki mitu jagiellońskiego w historiografii i publicystyce polskiej XIX wieku. Karol Szajnocha i Julian Klaczko. „Przegląd Humanistyczny” 1988, nr 11-12, s. 48. 
Krajowcy uznawali prymat interesów całej ludności kraju nad interesami każdej z grup narodowościowych. Jednocześnie jako reprezentanci społeczności polskiej nie godzili się na traktowanie Polaków na Litwie jako mniejszości, lecz jako jednego z trzech elementów historyczno-państwowych i kulturowych kraju. Hasło całości i niepodległości Litwy historycznej łączyli oni z postulatem równouprawnienia wszystkich zamieszkujących kraj narodowości23.

W Dialogu o Wilnie z grona krajowców Miłosz wyróżnia Ludwika Abramowicza, należącego, według jego słów, do spadkobierców „szerokiego myślenia, na miarę ludzi oświeconych w osiemnastowiecznej dawnej Rzeczypospolitej"24. Należy jednak wskazać na bliskość poglądów Miłosza z wczesnymi poglądami Michała Römera, jednego z ideologów krajowców wileńskich. W roku 1906 w artykule programowym wydawanej przez siebie „Gazety Wileńskiej” pisał on o konieczności ustalenia „współżycia rozmaitych elementów kulturalnie-narodowych w obu krajach, na szczerym stanowisku wspólnego obywatelstwa krajowego" 25 . Römer wierzył, że tylko w takim obywatelskim współżyciu wzmocni się wzajemne oddziaływanie rozmaitych pierwiastków kulturowych, co dodatnio wpłynie na ogólny rozwój kultury. Tak samo jak Miłosz podkreślał on niepodzielności kultury Litwy:

Elementy kulturalne polskie, które już są w społeczeństwie i w kulturze litewskiej weszły w jej ciało i krew i nie dałyby się bezboleśnie usunąć, bo stanowią organiczne cząstki całości ${ }^{26}$.

Zarówno Römer, jak i Miłosz, zdawali sobie sprawę z kluczowego miejsca, jakie Wilno zajmuje w sporze polsko-litewskim, będąc ośrodkiem skupiającym jak w soczewce podstawowe i najbardziej nabrzmiałe problemy tego konfliktu. Fakt ten stanowi jedną z głównych przyczyn, dla których właśnie to miasto stanęło w centrum rozważań Dialogu o Wilnie. Według Römera, posiadanie Wilna daje prawo do odziedziczenia tradycji Wielkiego Księstwa Litewskiego, co było ważne tak dla Polaków, uznających to miasto za integralną część ich kultury, jak i dla Litwinów, którym Wilno jako stolica Wielkiego Księstwa było nieodzowne dla legitymizacji swej państwowości:

(...) jako ośrodek kultury i inteligencji, otoczony w dodatku aureolą tradycyi historycznej, Wilno już dziś jest jabłkiem niezgody, o które walczy kilka narodowości. Posiadanie Wilna stanowi tytuł do posiadania kraju, bo ono jest sercem politycznohistorycznej Litwy. Polacy ze względu na doniosłą rolę, którą Wilno odegrało w rozwoju kultury polskiej, ze względu na tradycyę dawnego Uniwersytetu Wileńskiego,

\footnotetext{
${ }^{23}$ J. Bardach, O dawnej i niedawnej Litwie. Wydawnictwo Naukowe UAM, Poznań 1988, s. 265.

${ }^{24}$ Dialog o Wilnie, op. cit., s. 8.

25 [M. Römer] Od Redakcyi. „Gazeta Wileńska” 1906, nr 1, s. 1.

${ }^{26}$ M. Römer, Stosunki etnograficzno-kulturalne na Litwie. Krytyka, Kraków 1906, s. 18-19.
} 
który był gniazdem i kuźnicą tej kultury w pierwszem trzydziestoleciu XIX wieku, który wydał tak drogie kulturze polskiej największe jej imiona i sławy - Mickiewicza, Słowackiego, Śniadeckich, Lelewela i innych - ze względu też na przewagę obecną narodowości polskiej wśród ludności wileńskiej uznają Wilno za miasto polskie i nie chcą się swego stanu posiadania wyrzekać. Specjalnie zaś nacyonaliści polscy tam ostrzej w dodatku bronią polskości Wilna, że chcą go użyć za placówkę bojową, za klucz do spolszczenia kraju, za narzędzie zaborczej polityki narodowej.

Z drugiej strony Litwini, powołują się na najstarszą tradycję historyczną i uznając Wilno za kolebkę samodzielnej kultury i państwowości litewskiej (...) zgłaszają swe prawa historyczne do Wilna, grodu Giedymina, Jagiełły i Witolda ${ }^{27}$.

Zdaniem Miłosza, proponowane przez krajowców rozwiązanie sprawy Wilna i konfliktu polsko-litewskiego na podstawie obywatelstwa krajowego zapewniłoby ciągłość tradycji historycznej i kulturowej oraz pozwoliłoby utrzymać bogatą swoją rozmaitością wspólnotę narodową kraju:

Bo gdybyśmy uważali siebie za Litwinów, to Wilno byłoby naszą stolicą, naszym centrum. (...) Zasadniczo powinniśmy byli uważać się do Litwinów o języku rodzimym polskim i kontynuować w nowych warunkach Mickiewicza „Litwo, ojczyzno moja”, co znaczyłoby tworzyć literaturę litewską w języku polskim, jako równoległą do literatury litewskiej w litewskim. Ale przecież nikt tego nie chciał - ani Litwini, najeżeni obronnie wobec kultury polskiej jako wynaradawiającej, ani ci wszyscy mówiący po polsku, uważający siebie po prostu za Polaków i odnoszący się pogardliwie do "kłausiuków" narodu chłopów ${ }^{28}$.

Kontynuatora idei jagiellońskiej Miłosz widzi również w postaci Piłsudskiego, o którym z pewną sympatią wspomina w swoim liście, choć jego idei nie podejmuje w tym miejscu. Szerzej o Piłsudskim pisze w Wyprawie w Dwudziestolecie, gdzie nazywa go „naszym człowiekiem”, wskazując na jego litewskie pochodzenie, „przywiązanie się do Wielkiego Księstwa Litewskiego jako ojczyzny” jak i głęboki patriotyzm państwowy ${ }^{29}$. Przedstawiając wypracowaną przez Piłsudskiego koncepcję federacyjną, Miłosz uwydatnia elementy zbliżające ją do tradycji Rzeczypospolitej Obojga Narodów oraz wizji państwa lansowanej przez krajowców. Jednocześnie pomija nadrzędną rolę, jaką w planowanym państwie miała pełnić Polska ${ }^{30}$ :

${ }^{27}$ Ibidem, s. 9.

${ }^{28}$ Dialog o Wilnie, op. cit., s. 7-8.

29 W. Paruch, Obóz pitsudczykowski (1926-1939), w: J. Jachymek, W. Paruch (red.), Więcej niż niepodległość. Polska myśl polityczna 1918-1939. Wydawnictwo Uniwersytetu Marii Curie-Skłodowskiej, Lublin 2005, s. 73.

30 Przeciwnie niż Miłosz Michał Römer w latach czterdziestych już dość krytycznie odnosił się wobec koncepcji federacji Piłsudskiego, nazywając ją „imperium dominiów polskich”, w którym według niego Polska miałaby dominującą, przewodnią rolę. Patrz: M. Römeris, Juozas Pilsudskis 
(...) przystępował w 1918 roku do budowy państwa, takiego jakiego wymagała przechowywana w jego domu tradycja, tzn. Rzeczypospolitej Obojga Narodów. Państwo to byłoby chronione od wschodu przez połączone z nim przymierzem Litwę, Białoruś i Ukrainę, co najwyraźniej odtwarzało układ rodem z Unii Lubelskiej ${ }^{31}$.

Najważniejsze dla Miłosza było to, że w ustroju państwowym, zbudowanym na tradycji I Rzeczypospolitej, zostałaby zachowana ciągłość historyczna i kulturowa, a Wilno odzyskałoby range stolicy Litwy. W Dialogu o Wilnie poeta kilkakrotnie powtarzał, że miasto to powinno być stolicą, bowiem ten status „automatycznie usuwa jakieś polskie roszczenia do "polskiego Wilna«"32. W tym miejscu należy podkreślić, że tak jak krajowcy i Piłsudski, uważał on Wilno za stolicę nie Litwy etnograficznej, lecz Wielkiego Księstwa Litewskiego. Nie posiadając tego statusu, przedwojenne Wilno, będące początkowo stolicą sztucznego tworu państwowego - Litwy Środkowej, otrzymywało charakter enklawy, stając się tym samym prowincją ziem polskich, mogącą cieszyć się wyłącznie resztkami dawnej tradycji historycznej dzielonej poprzez strony polską i litewską. Taki stan rzeczy konstatował poeta słowami: "ni to Polska, ni to nie Polska, ni to Litwa, ni to nie Litwa, ni to prowincja, ni to stolica, choć przede wszystkim prowincja”33.

Zupełnie inny obraz Wilna wynika z listu rozmówcy Miłosza, Tomasa Venclovy. Jak sam przyznaje, jego Wilno i Wilno Miłosza to "krańcowo różne miasta”. W ujęciu Venclovy jest stolicą współczesnej Litwy, a nie Wielkiego Księstwa Litewskiego. Ciągłość historyczną po wojnie odnajduje on jedynie w architekturze nadającej miastom „aurę"34, której też poświęca sporo miejsca w swoim tekście. Venclova jest wychowankiem powojennego Wilna. W związku z tym nie miał już okazji usłyszeć o wileńskich krajowcach, zaś konflikt polsko-litewski określił mianem „piramidalnego głupstwa”. Venclova wierzy, że dawno znikły przyczyny tego konfliktu, a pozostałą bojaźń Litwinów wobec polonizacji i „nawyk demonizowania Polaków” zalicza do przestarzałych kompleksów historycznych narodu litewskiego. Jego zdaniem, kompleksy te związane są z faktem zdobycia przez Litwinów świadomości narodowej w opozycji do polskości. Tworząc swoją - często „odwrotną” do polskiej - interpretację dziejów i pamiętając o kulturowej dominacji Polaków, która zagroziła w XVIII wieku utratą litewskości, doprowadzono na Litwie do zakonserwowania stereotypu. Jak zauważa poeta, to właśnie pamięć

(1935), w: E. Aleksandravičius (red.), Lietuviu atgimimo istorijos studijos. T. 3, Žaltvykslè, Vilnius 1991, s. $460-461$.

${ }^{31}$ Cz. Miłosz, Wyprawa w Dwudziestolecie. Wydawnictwo Literackie, Kraków 1999, s. 10.

32 Dialog o Wilnie, s. 8.

33 Ibidem, s. 6.

${ }^{34}$ Ibidem, s. 17. Tu trzeba dodać, że za parę dziesięcioleci Venclova w Wilnie opublikuje trzy książki poświęcone jego historii i architekturze: Vilnius: vadovas po miestą. R. Paknio leidykla, Vilnius 2001; Vilniaus vardai. R. Paknio leidykla, Vilnius 2006; Vilnius: asmenine istorija. R. Paknio leidykla, Vilnius 2011. 
o tym zagrożeniu oraz bolesne poczucie podrzędności narodowej także dzisiaj przeszkadza w porozumieniu między obydwoma narodami. Venclova potwierdza pozytywny wpływ Polski na Litwę po Unii Lubelskiej, jak również prawa Polaków do Wilna jako ośrodka swojej kultury. Podkreśla jednocześnie wartość różnorodności tradycji i języków. Tym samym stanowczo wypowiada się przeciwko lituanizacji na Wileńszczyźnie. Ważąc starannie wszelkie „za” i „przeciw” poeta dochodzi jednak do wniosku, że dla Litwinów to miasto ma większe znaczenie, bowiem bez niego Litwa traci podstawę swojej państwowości:

Dla Polaków Wilno było ośrodkiem kulturalnym na Kresach, ważnym, ale przecież prowincją. Dla Litwinów to symbol ciągłości oraz tożsamości historycznej, coś w rodzaju Jerozolimy. W dziewiętnastym i dwudziestym stuleciu wyobraźnię litewską w znacznej mierze kształtował mit Wilna królewskiego i świętego, wydartego przemocą. (...) Więc idzie w sporze o Wilno (...) o rangę historyczną tego miasta: czy musi być regionalne centrum, czy może znajdować się w rzędzie tradycyjnych stolic wschodnioeuropejskich. Idzie także o rangę i trwałość Litwy. Bo Litwa bez Wilna jest państwemefemerydą, a z Wilnem zdobywa całą swoją przeszłość i całą historyczną odpowiedzialnośćs 35

Trzeba podkreślić, iż Venclova w odróżnieniu od Miłosza postrzegał siebie w szerszym kontekście wschodnioeuropejskim, podkreślając tym samym swoją przynależność do nieprzyswojonego polskiemu poecie świata wartości. Tym samym Wilno w jego wizji historycznej staje się jednym z ośrodków, "gdzie rodzi się nowa formacja wschodnioeuropejska" dysydentów antysowieckich, do której zalicza również Miłosza ${ }^{36}$.

Dialog o Wilnie skierowany był głównie do emigracji polskiej i litewskiej. Miał dać przykład tolerancji, odrzucając za razem pretensje Polaków do „naszego Wilna", jak i chęć Litwinów do odseparowania się od polskości. Litewska emigracja zapoznała się z treścią Dialogu o Wilnie wcześniej niż został on opublikowany. Jego tekst po raz pierwszy przeczytano publicznie na zjeździe organizacji emigrantów litewskich o kierunku liberalnym „Santara-Šviesa“, który miał miejsce w dniach 7-10 września 1978 r. w Tabor Farmie w Stanach Zjednoczonych. W wydarzeniu tym uczestniczyli obydwaj poeci ${ }^{37}$. Natomiast na samej Litwie tekst ten prawie nie był znany. W warunkach ostrej cenzury panującej w ramach systemu sowieckiego, paryska „Kultura” należała do pism wyjątkowo rzadko występujących nawet w konspiracyjnym drugim obiegu. Dlatego nie można zgodzić się z Elżbietą Sawicką, twierdzącą, że Dialog o Wilnie został przyjęty w kręgach intelektualnych Polski i Litwy z wielką uwagą ${ }^{38}$. O Dialogu na Litwie głośniej zaczęto mówić do-

\footnotetext{
${ }^{35}$ Dialog o Wilnie, s. 31-32.

36 Ibidem, s. 35.

37 V. Daujotytè, M. Kvietkauskas, Lietuviškieji Česlovo Milošo kontekstai, op. cit., s. 294.

${ }^{38}$ E. Sawicka, Dwa mury, op. cit., s. 8.
} 
piero $\mathrm{w}$ okresie tzw. odrodzenia, kiedy ponownie pojawiła się potrzeba uregulowania stosunków polsko-litewskich. Właśnie wtedy, w marcu 1989 r., reagując na odnawiający się konflikt polsko-litewski i dotrzymując danej w Dialogu obietnicy wypowiedzenia się przeciwko przymusowej lituanizacji na Wileńszczyźnie, Tomas Venclova wystąpił w paryskiej „Kulturze” z Listem otwartym do Litwinów $i$ Polaków litewskich ${ }^{39}$, przedrukowanym też w „Tygodniku Polskim” i magazynie „Lithuania”. W tekście swym Venclova potępił ówczesną politykę władz Litwy stosowaną wobec mniejszości. Broniąc wartości wielonarodowej i wielokulturowej tradycji Wileńszczyzny, litewski poeta starał się zburzyć zakorzenione na Litwie kompleksy i mity narodowe, oparte na jednostronnym i tendencyjnym interpretowaniu historii, które, jak podkreślał, jedynie jątrzą konflikty między Litwinami a Polakami, nie pozwalając osiągnąć zgody.

W ślad za Venclovą w paryskiej „Kulturze” wystąpił Miłosz, publikując artykuł opatrzony tytułem: O konflikcie polsko-litewskim. W tekście poeta potępił wrogi stosunek Polaków litewskich wobec odbywających się w tym czasie na Litwie demokratycznych przemian. Apelował równocześnie do wszystkich o wspieranie wolnościowych aspiracji Litwinów. Przy tej sposobności Miłosz jeszcze raz wyjaśniał czytelnikom genezę konfliktu narodowego, utrzymując, że "jedynie jasne uświadomienie sobie przeszłości może prowadzić do rewizji tych sposobów myślenia, które przyjmowane są bezrefleksyjnie, mocą nawyku, i które są jałowe" 40 . Polski poeta wykazywał swoje zrozumienie dla chęci Litwinów do odgrodzenia się od polskości. Tłumaczył ten fakt ich lękiem przed polonizacją. Nie usprawiedliwiał jednak wysiłków w udowadnianiu litewskości dziedzictwa kulturowego Wielkiego Księstwa. Twierdził, że nie jest to zgodne z prawdą historyczną, gdyż szlachta litewska w ciągu kilku wieków została spolonizowana, a Wilno i jego uniwersytet były polskie. Mówiąc o przyczynach konfliktu polsko-litewskiego, poeta zwracał uwagę na różnice występujące między szlachecką kulturą polską a chłopską kulturą litewską, która, oprócz starć narodowych, wywoływać miała, jego zdaniem, starcia na tle stanowym. W artykule Miłosz starał się rysować wizję dwujęzycznego państwa, przywołując jako wzór Irlandię. Tu przynależność do narodu określałby nie język, lecz „wola danej zbiorowości bycia razem”. W takim państwie również i on, jak twierdził, byłby "poetą litewskim języka polskiego".

Jak widać w omówionych w tym miejscu wypowiedziach, Venclova i Miłosz kontynuują zaprezentowane po raz pierwszy w Dialogu o Wilnie linie ideowe. W ich ujęciu główną wartość stanowić powinno harmonijne współżycie różnych narodów i kultur. By osiągnąć postulowaną rzeczywistość każda ze stron powinna jednocześnie wyrzec się pretensji do dominowania. Poeci nie usprawiedliwiają

${ }^{39}$ T. Venclova, List otwarty do Litwinów i Polaków na Litwie. „Kultura”, 1989, nr 3, s. 111-114; przedr. „Tygodnik Polski”, 1989, nr 21, s. 16; „Lithuania”, 1990, nr 1, s. 154-156.

${ }^{40}$ Cz. Miłosz, O konflikcie polsko-litewskim. „Kultura”, 1989, nr 5, s. 8. 
prowadzących do konfliktu postaw swoich rodaków. Przeciwnie, pokazują błędność ich wąsko pojmowanych poglądów, proponując rewizję prezentowanych postaw i nastawien, dotyczących kwestii narodowościowych.

Po raz kolejny 22 maja 1990 r., obaj artyści mieli możliwość zabrania głosu w sprawie stosunków polsko-litewskich. Wystąpienie poetów stanowiło nawiązanie do rozważań rozpoczętych jedenaście lat wcześniej na łamach paryskiej „Kultury". Bezpośrednim powodem wspólnego wystąpienia poetów stała się dyskusja zorganizowana $\mathrm{w}$ murach Uniwersytetu Jagiellońskiego $\mathrm{z}$ okazji odzyskania niepodległości przez Litwę ${ }^{41}$. Zasadniczym jej celem było wytyczenie drogowskazów do budowy stosunków polsko-litewskich w nowych demokratycznych warunkach politycznych. I tym razem Miłosz i Venclova konsekwentnie zajęli uprzednio wypracowane stanowiska. W centrum uwagi poetów znowu znalazła się tradycja Wielkiego Księstwa Litewskiego, wielonarodowe i wielokulturowe Wilno, jego uniwersytet, a także szukanie sposobów na uregulowanie stosunków polskolitewskich. Godnym odnotowania jest fakt całkowitego ujednolicenia postulatów podnoszonych przez poetów. Śmiało można powiedzieć, że krakowski dialog zmienił swój charakter, stając się jednogłosem. Rozważając pounijną historię Litwy, poeci uwydatnili ciągłość tradycji kulturowej Wielkiego Księstwa, pomimo metamorfoz językowych, które dokonały się w ciągu kilku wieków. Widzieli $\mathrm{w}$ nich jedynie naturalny przebieg tych procesów, w których konsekwencji część ludności Litwy, przede wszystkim wyższe warstwy, podległy polonizacji, zachowując przy tym świadomość odrębności od Polski i litewski patriotyzm państwowy. W rozumieniu poetów, patriotyzm państwowy ma zastąpić wąsko rozumiany patriotyzm narodowy, co pozwoli rozwiązać problemy mniejszości narodowych na Litwie. Jako przykład pozytywnych patriotów Miłosz tradycyjnie podaje krajowców wileńskich, m. in. Józefa Mackiewicza ${ }^{42}$. Krajowcy ci, jego zdaniem, sprzeciwiając się polskiemu i litewskiemu nacjonalizmowi, starali się zachować ciągłość tradycji Wielkiego Księstwa i całość jego dziedzictwa kulturowego. Z nurtem tym wiązał też masonów, którzy, jak zauważał, zajmowali ważne miejsce w życiu przedwojennego Wilna. W nieco później przeprowadzonym wywiadzie Miłosz objaśniał swoje sympatie do masonerii, które opierał na jej antynacjonalizmie. Uważał za niezwykle pozytywny fakt to, iż: „masoneria w Wilnie była elementem łagodzącym tarcie narodowościowe" 43 .

${ }^{41}$ Cz. Miłosz, T. Venclova, Rozmowa o Litwie. "Odra” 1991, nr 1, s. 23-33. Rozmowa została opublikowana też w dodatku „Gazety Wyborczej”: Mitosz-Venclova. Jak Litwin z Polakiem. „Gazeta i Nowoczesność" 1990, nr 27, s. 1-3, nr 28, s. 1, 6.

${ }^{42} \mathrm{~W}$ artykule poświęconym pamięci Mackiewicza z pewną sympatią mówił o jego patriotyzmie krajowym i niechęci wobec ideologii nacjonalizmu: „Mieszkał w mieście, które było dla niego nadal stolicą Wielkiego Xięstwa Litewskiego był tego kraju patriotą. (...) tacy jak on z równą niechęcią odnosili się do patriotów polskich, jak do patriotów litewskich czy białoruskich". Cz. Miłosz, Koniec Wielkiego Xięstwa. (O Józefie Mackiewiczu). „Kultura” 1989, nr 5, s. 102-120.

43 I. Grudzińska-Gross, Czy poeci mają się lubić?, "Gazeta Wyborcza” 1998, nr 208, s. 13. 
Mówiąc o wspólnej tradycji polsko-litewskiej, Venclova podkreślał olbrzymi dodatni wpływ kultury polskiej na Litwie, zwłaszcza w XIX wieku. Jego zdaniem, środowisko Uniwersytetu Wileńskiego i romantycy wileńscy odegrali znaczącą rolę $\mathrm{w}$ odrodzeniu się świadomości litewskiej, a przekłady romantyków zastąpiły romantyzm litewski, dając „wspaniały mit Litwy jako przestrzeni sakralnej, w której odbywa się to, co najważniejsze" 44 . Jego zdaniem, Polska dla Litwy zawsze oznaczała cywilizację światową, która przenikała do Litwy przez Polskę. Nawet po czterdziestym piątym roku, co podkreślał, język polski stanowił okno na literaturę światową, która dostawała się na Litwę dzięki polskim przekładom.

Szczególną uwagę w Rozmowie o Litwie poświęcono kwestii języka, która od początku do dziś zajmuje bardzo ważne miejsce w konflikcie polsko-litewskim. Zważając na istotną rolę języka litewskiego w budowaniu tożsamości narodowej w XIX wieku, Miłosz stwierdził dobitnie: „Litwa została stworzona bardziej przez filologię niż przez historię" 45 . Tym faktem objaśnił przyjętą na Litwie negatywną ocenę Unii Lubelskiej, skutkującej powolną polonizacją litewskich klas wyższych. Miłosz w swojej wypowiedzi kilkakrotnie wskazywał na bojaźn „roztopienia się w słowiańskiej mowie", która głęboko utkwiła w pamięci narodu litewskiego. Zdaniem Venclovy, wskazywany przez Miłosza lęk powodował niepotrzebną tendencję dopatrywania się w procesie polonizacji „demonicznej intrygi polskiej”. Obnażając litewskie mity i kompleksy historyczne, poeta wypowiedział się za prawem narodów do rozwoju własnego języka i kultury oraz potępił każdy objaw nietolerancji językowej.

Można stwierdzić, że główną treścią Rozmowy o Litwie stało się szukanie wspólnoty narodów litewskiego i polskiego, poprzez wskazywanie na nierozłączność ich historii, kultury i literatury. Wytyczając drogę stosunkom polskolitewskim, poeci, podobnie jak w swoich wcześniejszych wypowiedziach, powoływali się na tradycję historyczną Wielkiego Księstwa Litewskiego, proponując zastąpienie patriotyzmu narodowego patriotyzmem państwowym, równocześnie podkreślając wartość współżycia oraz współdziałania różnych narodów i kultur.

Idee głoszone przez poetów pozostawały jednak w sferze postulatów dalekich i obcych światu polityki. Świadczy o tym choćby fakt wysunięcia przez stronę litewską żądania potępienia przez Polskę akcji zbrojnej gen. Lucjana Żeligowskiego w 1920 r. oraz uznania polskiej obecności w międzywojennym Wilnie za okupację. Reagując na tę kwestię, Miłosz i Venclova w rozmowie z Elżbietą Sawicką, opublikowanej w „Rzeczypospolitej”, wspólnie odnieśli się do roszczeń strony litewskiej. Ostrzegli przed niebezpieczeństwem sięgania w przeszłość i mnożenia pretensji w stosunkach międzynarodowych, które prostą drogą prowadzą do zadrażnień i eskalacji konfliktów. Ponadto Venclova ostro skrytykował swoich rodaków za tendencyjne traktowanie polskich działaczy. Jak zauważył, odruchy tego

\footnotetext{
${ }^{44}$ Cz. Miłosz, T. Venclova, op. cit., Rozmowa o Litwie, s. 27.

${ }^{45}$ Ibidem, s. 24.
} 
typu nie przynoszą żadnych korzyści, uwydatniając jedynie litewskie kompleksy historyczne i brak zaufania do siebie ${ }^{46}$.

Okazja do ostatniej, wspólnej wypowiedzi poetów w sprawie relacji polskolitewskich nadarzyła się $\mathrm{w}$ październiku $2000 \mathrm{r}$. Było to wileńskie spotkanie z udziałem Wisławy Szymborskiej i Güntera Grassa przeprowadzone w cyklu „Litewsko-niemiecko-polskie rozmowy o przyszłości pamięci”. W swoim referacie pt. Wilno Miłosz jeszcze wyraźniej i ostrzej sformułował to, o czym mówił wielokrotnie wcześniej. Ogłosił swą otwartą niechęć do wszelkiego rodzaju nacjonalizmów i etnicznych podziałów:

Niestety, przyjeżdżając do Wilna zawsze mam wrażenie, że trzeba tu chodzić, jak po cienkim lodzie i że nie wystarcza tutaj być człowiekiem, każdego natychmiast zapytają, czy jest Litwinem, czy Polakiem, Żydem czy Niemcem, jakby ponury wiek dwudziesty, wiek etnicznych podziałów, trwał tu dalej w najlepsze ${ }^{47}$.

Poeta zakwestionował również definicję narodowości, opartą na kryterium językowym. Przeciwstawił jej rozumienie narodu w sensie, jak to określił, mickiewiczowskim. Dlatego też, w tym miejscu, Miłosz potępił rząd litewski z czasów drugiej wojny światowej za wprowadzenie w roku 1940 nowych dowodów osobistych. Zabieg ten zmusił mieszkańców świeżo przyłączonego kraju wileńskiego do określenia swojej narodowości, pozbawiając ich tym samym możliwości bycia Litwinami w sensie krajowym. Analizując wystąpienie z 2000 r. możemy zapoznać się także z Miłoszowskim rozumieniem "krajowości” stawianej w opozycji do „kresowości” jako wskazującej na peryferyjność:

Nie zasługuję bynajmniej na miano człowieka „z kresów”, nawet nazwa ta mnie drażni. Nigdy w mojej rodzinie tego słowa, zastosowanego do nas, nie słyszałem. Przeciwnie: byliśmy stąd, tzn. z dawnego Wielkiego Księstwa Litewskiego, a głównymi miastami naszego obszaru dla moich przodków było Wilno i Ryga ${ }^{48}$.

Nieprzypadkowo identyczne ujęcie odnajdujemy w programie krajowców wileńskich:

(...) w określeniu stanowiska naszego, musimy się kierować potrzebami krajowemi i w nich szukać punktu wyjście dla wszelkiej akcji politycznej, społecznej i kulturalnej. Z tego też względu odrzucamy stanowisko, tak zwanych, „kresów”, które kraje nasze Litwę i Białoruś - traktują jako satelity czyjeś, których rozwój i bieg ma być określony prawami ciążenia ku jakiemukolwiek ośrodkowi zewnętrznemu ${ }^{49}$.

46 Żeligowski i upiory przeszłości. Z Czestawem Miłoszem i Tomasem Venclova rozmawia Elżbieta Sawicka, „Rzeczypospolita” 1993, nr 149, s. 22.

${ }^{47}$ Cz. Miłosz, Wilno, w: Pokalbiai apie atminties ateiti, op. cit., s. 80.

${ }^{48}$ Cz. Miłosz, Wyprawa w Dwudziestolecie, op. cit., s. 9.

49 [M. Römer] Od Redakcyi. „Gazeta Wileńska” 1906, nr 1, s. 1. 
W referacie wygłoszonym w Wilnie Miłosz z ubolewaniem mówił o utraconej możliwości zachowania tradycji historycznej Wielkiego Księstwa Litewskiego i zbudowania państwa, którego fundament oparty byłby na równouprawnieniu zamieszkujących w nim narodów, języków i kultur. Również ten wątek można odnaleźć u przedwojennych krajowców wileńskich, do których tak często nawiązywał poeta $\mathrm{w}$ swoich wypowiedziach. Według niego, likwidacja Uniwersytetu Stefana Batorego w 1939 r. była wielkim błędem władz litewskich, ponieważ „właśnie środowisko profesorów tego uniwersytetu zachowało przywiązanie do tradycji Wielkiego Księstwa i sprzeciwiało się nacjonalizmowi polskiemu, dla którego Wilno było po prostu częścią Polski. (...) Gdyby uniwersytet dalej działał, przyczyniłby się zapewne, budząc litewski patriotyzm niezależnie od narodowości, do duchowej integracji Wilna z całością Litwy"50. Zdaniem Miłosza, litewscy nacjonaliści nie byli w stanie przejąć dziedzictwa historycznego i kulturowej tradycji byłego państwa, dlatego przedstawiali selektywny i wypaczony pogląd na swoją przeszłość, m. in. tworząc mit litewskiego Wilna:

Sentymentalny patriotyzm skłania ich do radości i triumfu, bo odzyskana została stara stolica Litwy. Szukają też śladów litewskości pod pokostem polonizacji i szczycą się litewskim pochodzeniem architekta Gucewicza. A przecie wiedzą zarazem, że to tylko powierzchnia, słowa na użytek publiczny, i że każdy z nich musi uporać się w samym sobie z o wiele trudniejszym problemem: jak uznać to całe dziedzictwo za swoje, jak włączyć się w łańcuch następujących po siebie pokoleń w tym mieście ${ }^{51}$.

Miłosz przypominał w swoim wystąpieniu, że przed wojną Wilno było miastem polskim i żydowskim ${ }^{52}$, dużo miejsca poświęcając Żydom, dla których Wilno było "Jerozolimą północy” - jednym z najważniejszych na świecie centrów kultury żydowskiej. Na przykładzie nawróconego na judaizm hrabiego Walentyna Potockiego, poeta pokazał nierozłączne powiązanie zamieszkujących w Wilnie narodowości, ich historii i kultur. Innym przykładem tego związku, którym posługiwał się Miłosz wielokrotnie dla potwierdzenia swoich twierdzeń, był romantyzm wileński. Utwory romantyków, jak zauważał, stworzyły „Litwę jako mityczną krainę odwiecznych lasów i pogańskich bogów", a także kształtowały tożsamość narodową Litwinów. Poeta, zdając sobie sprawę z wpływu, jaki na narody posiada zmitologizowana przeszłość, która bardzo często staje się orężem w walce politycznej próbował przeforsować swoją prawdę historyczną. Wierzył, że jego wersja

${ }^{50}$ Cz. Miłosz, Wilno, s. 92.

51 Ibidem. 96.

$52 \mathrm{~W}$ tym okresie 36,1\% ludności Wilna stanowili Żydzi, 2,3\% Litwini, 1,4 Białorusini, a pozostałą największą część - Polacy; patrz: Jerzy Smoleński, Mniejszości narodowe, w: Marian Dąbrowski (red.), Dziesięciolecie Polski Odrodzonej. Księga pamiątkowa 1918-1928. „Ilustrowany Kurier Codzienny”, Kraków-Warszawa 1928, s. 51. 
wyrastająca ponad partykularnymi interesami narodowymi, zmieni współczesną pamięć historyczną, tworząc dostateczne podstawy do osiągnięcia zgody.

Tomas Venclova podczas wileńskiego spotkania również skoncentrował się na kwestii pamięci historycznej. Twierdził, że misją pisarza $w$ jego społeczeństwie, jest pełnienie funkcji stróża pamięci, zbiorowej. Rozumiał przez to konieczność krzewienia szczerej i odpowiedzialnej pamięci generującej nie tylko doznane krzywdy, lecz także winy oraz długi ${ }^{3}$. Według niego, pisarz powinien stawiać opór selektywnej i zdeformowanej wizji przeszłości, którą proponują totalitaryzmy i nacjonalizmy. W końcu swego wystąpienia Venclova zakwestionował samo pojęcie narodu, określając go mianem hipostazji. Stwierdził ponadto, że przynależność językowa, która zależy też od wyboru osobistego, jest ważniejsza od przynależności narodowej. W tym miejscu należy zauważyć, że manifestowana postawa Venclovy, głosząca prymat tolerancji narodowej i kulturowej, była w głównej mierze oparta na wyznawanym przez niego kosmopolityzmie rozumianym w klasycznym sensie to jest jako stanowisko negujące podziały kulturowopolityczne i terytorialne "obywatelstwo świata". Poeta przedstawiał się w tym ujęciu następująco: „Co się tyczy mnie osobiście, to na Litwie jakichś dziesięć lat temu bywałem, a na emigracji bywam oczywiście posądzony o coś w rodzaju zdrady narodowej. No bo jestem kosmopolitą, judofilem, polonifilem, rusofilem nawet..."54. Przyjęta postawa odróżniała go w znaczący sposób od Miłosza, dla którego główny punkt wyjścia do wszelkich rozważań stanowiła tradycja Wielkiego Księstwa, będąca wzorem idei i wartości, na które powinni orientować się zarówno Litwini jak i Polacy w budowaniu wzajemnych stosunków. W jego wypowiedziach dawne Wielkie Księstwo Litewskie nabiera rangi utopii - idealnego państwa, bliskiego wizji krajowców wileńskich, zbudowanego według idei jagiellońskiej, w którym współżyły w symbiozie różne narodowości, języki, kultury i religie, złączone wspólnym hasłem patriotyzmu krajowego. Należy zwrócić uwagę, że szukając $\mathrm{w}$ przeszłości wzorów dla uzasadnienia wartości lansowanego przez siebie modelu mitycznej Rzeczypospolitej, Miłosz dokonuje selekcji. Eksponuje tylko te fakty, osoby i idee $\mathrm{z}$ historii stosunków polsko-litewskich, które pasują do tworzonej przez niego wizji. Obrazu, mającego zmienić wyobrażenia, kształtującego pamięć historyczną współczesnego społeczeństwa. Tu trzeba zauważyć, że jego koncepcja tolerancyjnego społeczeństwa, stającego ponad podziałami narodowymi i kulturowymi, zbliża się do idei społeczeństwa obywatelskiego. Właśnie społeczeństwo stanowiące zbiorowość świadomych swoich obowiązków wobec społeczeństwa jednostek, zdolne do samoorganizacji w celu działania na rzecz wspólnego dobra, przekraczające interesy indywidualne ${ }^{55}$, mogłoby, zdaniem

53 T. Venclova, Noréčiau matyti bebaimę atminti, w: Pokalbiai apie atminties ateiti, op. cit., s. 107.

${ }^{54}$ Dialog o Wilnie, op. cit., s. 35.

55 Por. J. Szacki, Wstęp. Powrót idei społeczeństwa obywatelskiego, w: J. Szacki (red.) Ani książe, ani kupiec: obywatel. Idea społeczeństwa obywatelskiego w myśli wspótczesnej. Znak, Kraków-Warszawa 1997, s. 35-38. 
polskiego poety, zapewnić harmonijne współżycie wszystkich jej obywateli, nie zważając na ich przynależność narodową i wyznaniową.

Rozważania litewskiego poety zaprezentowane w roku 2000 stanowią podsumowanie toczonej przez dwa dziesięciolecia dysputy z Miłoszem. Baczny obserwator powinien dostrzec $\mathrm{w}$ niej próbę wspierania pisarzy świadomych swojej misji wobec społeczeństwa i uczciwej pamięci o przeszłości, która powinna zmienić ukształtowane na przestrzeni wieków wyobrażenia o historii, stanowiące źródło mitów i stereotypów historycznych oraz kompleksów narodowych, przeszkadzających Polakom i Litwinom w dojściu do porozumienia. Poeci, dotykając najbardziej drażliwych kwestii stosunków polsko-litewskich, starają się pokazać ich korzenie, sięgające niekiedy dalekiej przeszłości. Wierzą, że tylko szczera rewizja stanowisk i zrozumienie istoty problemów pomoże zmienić podejście do nich i łatwiej znaleźć sposoby ich rozwiązania.

Wracając do pytania o miejsce dysputy Miłosza i Venclovy, trzeba przyznać, że chociaż doczekała się ona niemało uwagi w Polsce i na Litwie, to jej realny wpływ na współżycie obu narodów pozostawił wiele do życzenia. Nadal otwartą kwestię stanowią konflikty na tle narodowościowym. Wystarczy wymienić niedawny spór o używanie polskiej pisowni nazwisk i nazw miejscowości na Litwie, a także reformę szkolnictwa, która wywołała duże oburzenie nie tylko wśród litewskich Polaków, ale także odbiła się szerokim echem w całej Polsce ${ }^{56}$. Trwająca blisko ćwierć wieku dysputa nie wpłynęła nadmiernie na zmianę nastawień. Obydwie strony nadal kierują się argumentami używanymi od początku sporu polskolitewskiego. Trwająca sytuacja pokazuje, jak trudno zmieniać głęboko zakorzenione niechęci i obawy wyrosłe na stereotypach. Stan obecnych relacji polskolitewskich potwierdza jedynie konieczność kontynuowania zaczętej przez Miłosza i Venclovę pracy szczerego rewidowania historii oraz potrzebę otwartej i tolerancyjnej rozmowy, która jako jedyna może stać się środkiem prowadzącym do koniecznej przecież zgody.

${ }^{56}$ Według planu optymalizacji sieci szkół mniejszości polskiej na Litwie, powinny zostać zamknięte małe szkoły w małych miejscowościach. Oprócz tego, na podstawie nowej ustawy o oświacie przyjętej przez Sejm Republiki Litewskiej, od września 2010 roku w szkołach mniejszości narodowych przedmioty geografii i historii Litwy, a także podstawy obywatelskości powinny być prowadzone w języku litewskim. Dotychczas ten obowiązek dotyczył tylko przedmiotu języka litewskiego. Według wymienionej ustawy, od 2013 roku wszyscy abiturienci na egzaminie języka litewskiego będą mieli jednakowe zadania. Te reformy wywołały falę protestów. Polacy oskarżają stronę litewską o chęć likwidacji polskiej oświaty na Litwie i lituanizację litewskich Polaków. Por. J. Pawlicki, Polskie szkoty maja mówić po litewsku. "Gazeta Wyborcza”, 17.03.2011 r., <http:/ / wyborcza.pl/1,75477,9272204, Polskie_szkoly_maja_mowic_po_litewsku.html> [dostęp: 08.03.2012]. 


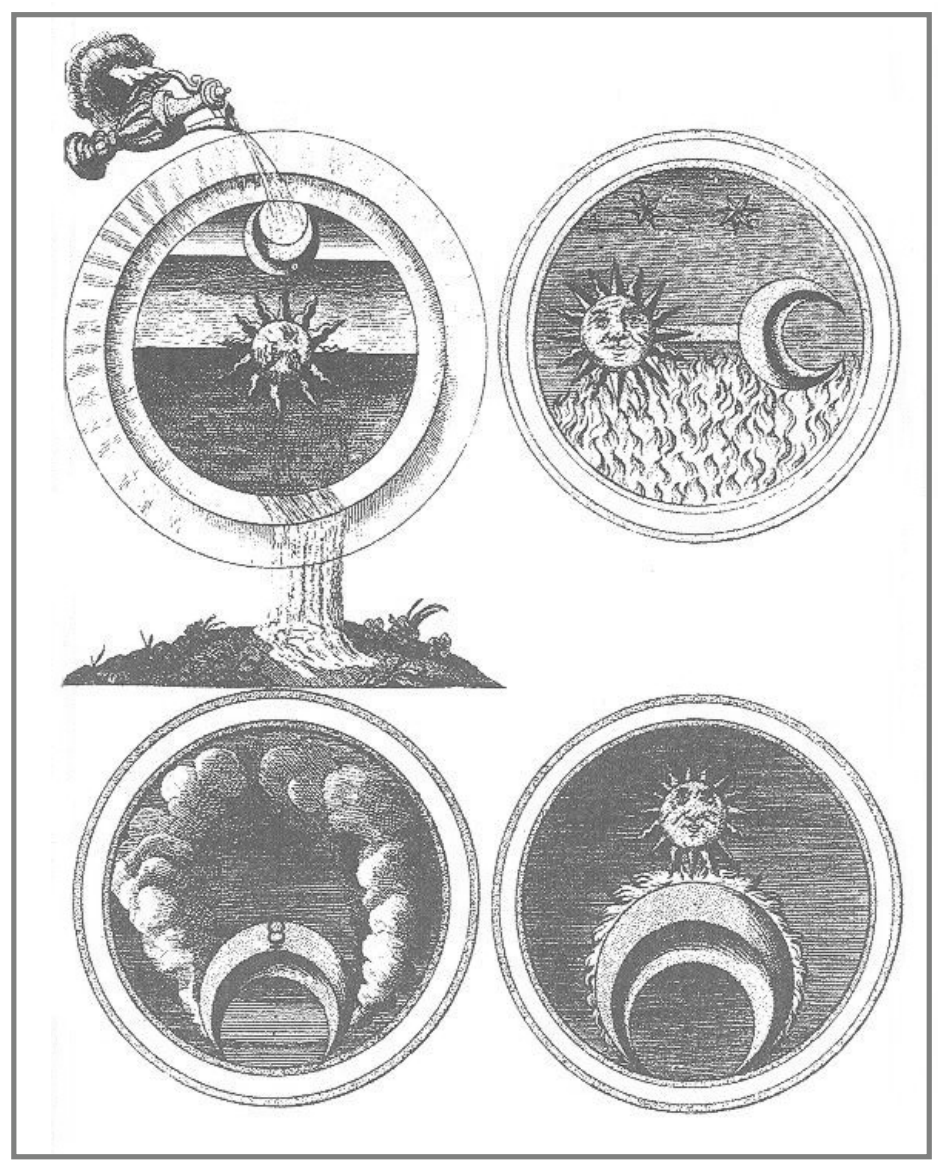

